\title{
DIGITAL TECHNOLOGIES FOR SUPPORTING THE MANAGEMENT PROCESSES OF TEACHER PROFESSIONAL GROWTH WITHIN THE DEPARTMENTS OF MANAGEMENT IN THE UNIVERSITIES OF THE REPUBLIC OF POLAND
}

\author{
Victor Oliynyk, Iryna M. Androshchuk \\ State Higher Educational Institution "University of Educational Management" of the NAES of Ukraine
}

\begin{abstract}
The article examines the possible forms of self-management of the teacher professional growth of the management departments in the universities of the Republic of Poland. The following forms of enhancement of the teacher professional level are analyzed as courses, studies, trainings and portfolio. Distance and open education are characterized as alternative forms of self-management of the teacher professional growth in Polish universities. It was established that teachers of management departments use information systems LMS, LCMS; digital platforms Moodle, ELIAS and USOS in the system of higher education of the Republic of Poland.
\end{abstract}

The types of e-learning are described, its possibilities and influence on the teacher professional growth are characterized within the management departments in the Polish universities. The questionnaires and interviews data are analysed for teachers of management departments in the universities of the Republic of Poland, in which the ways and forms are indicated for self-management of professional growth preferred by the teachers of the management departments of Polish universities. The role of digital technologies is analysed as an integral part in self-management of teacher professional growth in the modern conditions of globalization and European integration of Polish society.

Keywords: open education, distance learning, e-learning, professional growth, self-education, self-development, management, digital educational platforms, digital technology

\section{TECHNOLOGIE CYFROWE WSPARCIA PROCESÓW ZARZĄDZANIA ROZWOJEM ZAWODOWYM NAUCZYCIELI AKADEMICKICH KATEDR ZARZĄDZANIA UNIWERSYTETÓW POLSKI}

Streszczenie. W artykule rozważono możliwe formy samorozwoju nauczycieli katedr zarządzania uniwersytetów Polski. Przeanalizowano nastęujące formy podwyższenia kwalifikacji nauczycieli akademickich z wykorzystaniem technologii cyfrowych: kursy, szkolenia, seminaria, treningi, kształcenie podyplomowe. Została scharakteryzowana edukacja na odległość i edukacja otwarta jako alternatywne formy wsparcia procesu samozarządzania rozwojem zawodowym nauczycieli akademickich uczelni polskich. Ustalono, że w systemie szkolnictwa wyższego w Rzeczypospolitej Polskiej nauczyciele katedr zarządzania najczęściej korzystają z systemów informatycznych LMS, LCMS; platform cyfrowych Moodle, ELIAS i USOS.

Scharakteryzowano rodzaje e-learningu, opisano jego możliwości i wplyw na rozwój zawodowy nauczycieli katedr zarządzania uczelni polskich. Przeanalizowano dane kwestionariuszy $i$ wywiadów wspomnianych nauczycieli akademickich, podano wskazane przez osoby ankietowane sposoby i formy samorozwoju zawodowego, preferowane przez nich. Przeanalizowano rolę technologii cyfrowych jako integralnej części samodoskonalenia się nauczycieli w nowoczesnych warunkach globalizacji i integracji europejskiej polskiego społeczeństwa.

Słowa kluczowe: edukacja otwarta, nauczanie na odległość, e-learning, rozwój zawodowy, samokształcenie, samorozwój, zarządzanie, cyfrowe platformy edukacyjne, technologia cyfrowa

\section{Introduction}

Changes occur in consciousness, approaches to professionalism, determination of its level, forms and ways of its self-development in the times of rapid changes in world society, economy, science and technology. Actual Polish commonwealth of scientists frequently brings up the issue of creating conditions for continuing education for teachers. Polish universities increasingly afford access to educational, didactic, scientific materials and sources within the framework of open and distance education. Courses, trainings, conferences, seminars are offered both for lecturers and students through online mode. The elearning has become very popular offered by universities, state and non-state educational institutions, which organize qualification upgrading courses, trainings, courses, etc.

\section{Target setting}

The need for teacher self-development is beyond doubt in the Polish academic community, since everyone who works at a Polish (both state and private) university carries out selfassessments at the end of the academic year; his professional activity is also evaluated by students, heads of structural units of the university as departments, faculties, institutes, which makes the teacher constantly improve oneself and raise the professional level. Both the senior managers of Polish universities and the teachers themselves are aware that no one can plan teacher professional development management better than make it oneself. As far as this planning involves the assessment of real resources, the determination of the strategic goal, the pace setting and a time for its achievement.
Actual scientific researches and issues analysis

The problem of using digital technology is the subject of interest as an effective form of self-development support for many scholars. The place and role of digital technologies in the teacher professional development are explored among Ukrainian researchers by Y. Bykov, A. Gurzhii, L. Liahotska, S. Kasian, T. Mahyna, V. Oliynyk; the use of digital and cloud technologies in management is analyzed by V. Kamyshyn, N. Klokar, V. Oliynyk, Z. Ryabova, T. Sorochan; the problem of digital technologies is the subject of research among the Polish scientists by I. Garnik, V. Wojcik, A. Zapasa, L. Koziol, M. Koziol, J. Kolodziej, P. Komada, P. Kopcial, K. Redlarski; questions of personal and professional development are of interest to D. Becker-Pestka, J. Kolodziej, C. Pujer. However there is currently no comprehensive study analyzing the role of digital technologies in the process of supporting the teacher professional self-development within the departments of management in the universities of the Republic of Poland. That accounts for the urgency of this article.

\section{The objective}

The objective of the scientific intelligence is to characterize the most common forms of self-development of the teacher professional competence within the departments of management in Polish universities and to outline the significance of digital technologies in this process. 


\section{Theoretical and methodological framework of the research}

The analysis of the legal framework, scientific sources, university development strategies, questionnaires and interviews of teachers of the management departments in the state universities of the Republic of Poland provide grounds for arguing that the teacher professional growth takes place due to the planned processes of management and self-management in Polish universities. The professional growth of teachers and other employees is indicated for strategic purposes in the development strategies of Polish universities since the quality level of education offered to students depends on the teacher level of professionalism. We analyze the teacher self-development powered by digital technologies within management departments in the universities of the Republic of Poland in the framework of given intelligence rapidly developing and occupying a prominent place among all other innovative educational and managerial technologies.

We will represent the interpretation of the concepts of "profession" and "teacher" by Polish scientists in order to reveal the theoretical aspects of the above problem. According to T. Nowacki considered the creator of the pedagogical work in the Republic of Poland, "the profession means the implementation of a number of socially useful measures separated as a result of the division of labour requiring for the appropriate knowledge and skills from the employee as well as psychophysical features that determine the work of a professional, are systematically repeated and a source of funding for the worker and his family" [15, p. 287].

In the normative-legal framework of higher education of the Republic of Poland, the concept of "teacher" is defined as "nauczyciel akademicki - academic teacher (translated by author)". This person works in the higher education system as a didactic, scientific and didactic or just scientific worker. An academic teacher should be distinguished from a teacher working in school. According to the dictionary of occupational titles, which is current on the territory of the Republic of Poland, "academic teacher" is placed under the cipher 2311, and then specialties are listed for various fields. Teachers of the management departments belong to humanistic sciences - 231106 [14]

The analysis of theory and practice has confirmed the assumption that each teacher working in the management departments is a participant of the professional growth process. Teachers of the management departments in the universities of the Republic of Poland analyze and fix the following in order to plan their own professional growth: 1) the existing level of professionalism; 2) the expected level of professionalism in the close-up and distant perspective; 3 ) measures necessary to achieve the expected level of professionalism; 4) analyze required resources (human and material) for this purpose; 5) monitor their own professional activities.

Continuing education reflected in the Law on Higher Education in Poland plays a significant role in the selfdevelopment process of the teaching staff of the management departments. It concerns the renewal and deepening of general knowledge, skills and professional qualifications of both employees and employers [18]. Courses, seminars, trainings, internships constitute forms of continuing education for teachers in the Polish universities. It can be organized both at the place of work and away from it. Polish scholars unite forms of the education organization into two groups $[11$, p. 468-473]: away from the place of work including lecture, discussion and at the place of work including instruction, coaching, mentoring.

The purpose of courses and trainings is largely to expand the competencies of the employee in a particular industry. Training is characterized by systematic and planned nature. Trainings and courses allow the teacher to acquire the knowledge required to complete the tasks of the department and the university. It also creates opportunities for the satisfaction of the needs of the higher educational institution in the field of its staffing policy [11, p. 7].
Planned courses and trainings proceed on the basis of SWOTanalysis in Polish universities, aim at forming new competencies or developing existing ones at the level indicated for the near future by the teacher filling out the questionnaire. Scientists distinguish these definitions and emphasize that the course is a broader concept than training in the system of continuing education of the Republic of Poland [6, p. 61].

It is worth noting that postgraduate studies are one of the important forms of the teacher professional growth within the management departments. According to the Law on Higher Education of the Republic of Poland, postgraduate education is a mode of study that can be used by those who have the first degree (bachelor) [18]. This studies differ from the one described above with a specific structure and correspondence to the National Qualifications Framework. According to Polish law, the duration of studies is not less than two semesters and the result of training is the postgraduate thesis defence and obtaining a diploma complying with a certain qualification degree. $33 \%$ of respondents indicated that they had postgraduate education (second higher education, postgraduate studies, etc.) and $67 \%$ of teachers do not have such kind of education while questioning teachers of the management departments in the universities of the Republic of Poland. At the same time $89 \%$ of them obtained postgraduate education using distance or intramural and distance form of study.

There is a large number of hours for self-study namely selfeducation in the postgraduate studies programs. The concept of self-education is meant self-acquisition of knowledge in Polish scientific community. We agree with D. Jankowski, who notes that "self-education is a process, that is a number of logically interrelated, precisely organized actions of the person being trained who is aimed at an independent, rudderless obtaining the necessary information, intellectual and manual features as well as the development of such cognitive abilities as observation, attention, imagination, memory and critical thinking" [7, p. 120-121].

The teacher professional growth within the management departments and their qualification enhancement are associated with rapidly changing labour markets in Poland and the world. Technological and informational development of the world society has led to the fact that Internet and accordingly digital technologies affect the nature and content of continuing adult education in each industry.

Poland's Development Strategy until 2020 grounds the development of the digital society of the country on strengthening of three areas: infrastructure, content and services development as well as demand. First and foremost the latter requires the maturity of the digital competencies of individuals who do not use the Internet at all and development of the competences of individuals who are closely related to Internet and digital technologies and use it [13].

The report "Information Society in the Figures by the Ministry of Administration and Digitalization" (2014) states that "digital competences are a group of information competencies covering the ability to search for information, its understanding, assessment of its probability and suitability, informatics competencies, which are the ability to use a computer and other electronic learning tools, the Internet as well as various digital applications, programs, and create a digital content, as well as functional competencies, which are the ability to apply the above-mentioned competencies in practice" (translated by author) [17]. The digital competencies mean the knowledge, skills, high level of self-motivation and selfawareness in this case which allow effectively using of existing digital technologies in professional activity for teachers of the management departments in the universities of the Republic of Poland.

As a result of the intelligence analysis exploring the application of digital technologies we note that digital technology as we know it is an innovative technology using digital technique and information systems; the activity of technical, economic and organizational nature with an eye toward introducing digital devices and digital systems into the development of various 
sectors of the country. Dramatic changes have taken place in the system of higher education in the Republic of Poland during the last decade in the implementation of digital technologies in university education. Therefore, a problem appeared in the studies of teachers and university staff in order to form the competencies necessary for the use of digital technologies both in the educational process and in self-development support.

The introduction of open educational platforms is a topical issue in the university practice In the Republic of Poland: Polish specialists are working to create a platform for all teachers, which will give equal access to interactive educational materials from various subjects and will also offer an electronic journal of the same form for all universities. This platform should have educational digital content. It will include publications of educational content, information about vacancies for teachers, the possibility of raising the level of professionalism (planned courses, seminars, trainings, etc.).

It should be emphasized that a digital policy is carried into execution in the Polish society based on the digital education of the individual; this is a change in the attitude towards the digital world. Much attention is paid to the application of the cloud as a model for managing digital educational tools and learning environment. There is a comprehension of the need for simultaneous enhancement of the level of didactic and digital competencies among the participants in the educational process in the Republic of Poland; the concept of cyber-didactic competencies has been formed for this purpose. The goals of cyber-didactics include activating a "student" (a person who studies), providing interaction between a "student" (a person who studies) and a "teacher" (a person who teaches) and individualization of training (an individual training program in accordance with the "student's" requests).

The introduction of digital learning technologies has led to the emergence of a new system called e-learning and provides the opportunity to conduct training, courses, seminars and implement postgraduate learning through digital technologies. The use of the aforementioned system undoubtedly contributes to the effectiveness of self-education and planning of support for the teacher self-development.

The concept e-learning has several synonymous terms in the Polish language as "distance learning" and "online education". As scientists point out the great positive of such training is that the person while studying can raise his professional level at a convenient time and in a convenient place [10, p. 48]. E-learning is understood to be somewhat broader in scientific sources. It concerns learning supported by such tools as computer programs, platforms, electronic sites, pages, educational portals and services, teaching and didactic materials on electronic media [5]. E-learning requires high motivation for training. Those who study must develop their own will power, motivate themselves to work out the material, accomplish tasks, and acquire the digital learning technologies independently [3].

According to questionnaires, teachers of management departments often choose distance courses and training usually carried out using the e-learning platform. The reason for this is the material resources (savings on accommodation, travel), the combination of work and study (non-working time education), time management and the opportunity to study in a convenient place and at an appropriate pace. Teachers note that e-learning courses and training allow them to work with materials at a convenient time often checking the level of the acquired information, controlling their achievements in education, staying in touch with the authors of educational materials, moderators, tutors, having the opportunity to ask questions and promptly receive answers to it.

Teachers mostly use such components of the teaching materials on the platform as text; simple graphical and multimedia elements as photographs, drawings and animations; movies and audio files containing educational information; tests and tasks; various types of advancement questions and tasks, lexicons, auxiliary files, hyperlinks [19, p. 16].
Unfortunately, not all Polish universities fully use digital learning technology. The reason for this is largely the inadequacy of technical capabilities to the requirements; the attachment of senior managers of university and structural units to standard forms of education, the stereotype prevalence of the of middle and senior age teachers, who consider that the intramural form of education during courses, training and postgraduate education forms a higher level of professional competences. In this context $85 \%$ of the interviewed teachers aged 60 and older argue that selfeducation is effective working out books and articles in printed form in reading rooms of academic libraries or at home; while $90 \%$ of teachers under the age of 60 prefer internet resources, electronic books and electronic articles, visit electronic libraries belonging not only to universities of the Republic of Poland but also to other countries of the world, although do not reject the processing of printed sources. They also note frequently usage of such digital learning media as computers (laptops), tablets, multimedia whiteboards, projectors, and digital programs for creating educational projects.

The analysis of the university sites of the Republic of Poland confirms the fact that the number of educational digital platforms is increasing every year at state universities. Distance learning centers are established forming courses, trainings, seminars based on customer requests, their requirements and wishes; the drawback noted by the teachers is that such forms of e-learning offered by distance learning centres are paid. However teachers of the management departments note in questioning and interviewing that combination of traditional and innovative forms of training among which digital technologies are more and more popular embodies the future of both the Polish and world university education.

The combination of traditional forms of learning and e-learning is called blended learning or b-learning [19, p. 64-65]. As the analysis shows e-learning can completely duplicate the traditional form of learning in practical use taking into account the peculiarities of e-learning or supplement the traditional form of learning with the relation that the teacher who studies will determine for himself. Teachers of the management departments mentioned in the interview that they typically use b-learning.

The development of e-learning has led to the emergence of its two directions in Polish universities: corporate and academic [19]. Corporate e-learning is first of all directed to achieving the goal of increasing the competitiveness of the firm (in our case it is the University of the Republic of Poland) through the development of human resources (in this case it is the teaching staff of the management departments). "A characteristic feature of corporate e-learning is the fact that it can be performed apart from the educational institution" [9, p. 64]. As for academic e-learning it is "characterized by much wider goals than the improvement of the educational process and its economic processes" [9, p. 65]. This is due to the fact that academic e-learning has to fulfil practically all university functions and transfer the learning process to the network. The aforementioned areas of e-learning develop independently of each other and differ not only by objectives but also by methods and means serving its implementation.

The dominant types of information systems supporting e-learning in Polish universities are following [2, p. 29]:

- LMS (Learning Management System) is a system that allows to report, administer and monitor your academic achievements, manage your teaching materials and rights and also register for course participants;

- LCMS (Learning Content Management System) is a system that enables the creation, edition, access and management of didactic content; it ensures an opportunity to control the process, to create didactic content, as well as to archive it beyond the functions available under the LMS.

Moodle is the most common among the educational digital platforms used by universities in the Republic of Poland, since it has a free license and this significantly saves the budget of universities. 1500 connections to this platform are fixed in Poland 
[2, p. 30]. Digital platform ELIAS is also presented on the Polish market of higher education. Like Moodle, it has a modular structure but offers wider opportunities for individual user needs and also has the ability to integrate with other digital systems operating in the university and serving deans, academic communities and scholarship commissions that contain solemn information on didactic materials, announcements, vacancies or additional classes [2, p. 34].

Before long the USOS system (Uniwersytecki System Obsługi Studiów) is gaining in popularity, it was installed at the University of Warsaw at the Faculty of Mathematics, Computer Science and Mechanics in 2000 as the first version. The MUCI Consortium (Międzynarodowe Centrum Informatyzacji - International Informatization Center) was specially created to this end, which task was to develop and implement a management system of educational and organizational processes at the universities in the Republic of Poland. Such a system operates to the full extent in 17 state Polish universities. Many universities have implemented some of its capabilities as electronic student registration, electronic deans, electronic libraries, etc.

On-line services in the USOS system are carried out with the assistance of three-level architecture and associated with such free information and communication technologies as PHP, Smarty I Python.

Teachers of the management departments are quite active in the USOS system. It holds their workload, curriculum, schedule of classes and consultations, an individual support for students (tasks, decisions, tests, review works, assessments, scientific guidance on writing course papers and thesis). Many universities also have a public interface for integrating the USOS system with other electronic systems functioning in a higher educational institution - USOS API. USOS can also collaborate with the local systems of a specific university: an e-mail server, a central authorization server, e-learning on the Moodle platform, library systems.

Analysis of the digital platforms usage suggests by teachers of management departments in the universities of the Republic of Poland that they frequently use the USOS local system $-85.7 \%$ of respondents; $42.9 \%$ of teachers use the Moodle system; other platforms are used by $57.1 \%$ (respondents could choose several answers) [1].

A new culture has been formed in the digital environment in higher education of the XXI century: open digital educational means - e-means for formal education; e-textbooks, textbooks on the Internet (scattered, hypertext, multimedia). Polish students tend to have no formal textbooks, but digital analogues to printed textbooks. Inference should be drawn that the teacher of the Polish university must be the author of digital content. For this purpose Polish universities and institutions of non-formal education organize and conduct courses in order teachers to receive information and media education that is the ability to find information, analyze it, distinguish it from the false one, to process and create digital content based on standard documents. Moreover, the digital humanities should be adhered meaning to be able to combine humanistic and digital practices.

Despite the constant development of digital technologies in higher education in the Republic of Poland, there are many unresolved issues:

- dissonance between the student activity in the digital world (online life) and constraints dominated in Polish universities as well as the teacher perceptions of the Internet role in the life of students;

- presence of non-motivated teachers regarding the use of digital technologies in teaching activities and in professional self-development support;

- functioning university documents related to the digital world (password-protected Wi-Fi daily requiring for manually update IP-addresses, complications in access to digital means);

- absence of real (registered in normative documents) incentives and motives for introducing digital technologies into the educational process by teachers;
- misconception of senior managers of universities in the Republic of Poland and its structural subdivisions (institutes, faculties, departments) that acquisition of digital means and provision university staff with digital programs is the sufficient condition to support their professional growth and improve the quality of education.

\section{Research results}

In the context of the above, it was established that digital technologies play a significant role in supporting self-management of the teacher professional growth within the management departments in the universities of the Republic of Poland. Teachers note that the development of their professional competence takes place during seminars - 66.7\%; courses $33.3 \%$; internship $-33.3 \%$; trainings $-6.7 \%$. Concerning the availability of postgraduate education $33 \%$ of the questioned teachers reported the answer "yes", 67\% answered "no". At the same time $89 \%$ of them underlined that, all of the abovementioned forms of training were received through e-learning. All respondents acknowledged that they prefer e-learning, distance learning and open education while $57.1 \%$ of the questioned teachers of management departments used this form in their teaching activities in the universities of the Republic of Poland; $42.9 \%$ used as students.

\section{Conclusions and perspectives for further studies}

Taking into account the foregoing we can assert digital technology of support is dominant in the management of selfdevelopment of professional competence of teachers within the management departments of Polish universities. Continuing education in shape of courses, seminars, trainings, postgraduate education plays a crucial role in the process of the selfmanagement of teacher professional growth in Polish universities at the present stage of world society development. All of these forms of obtaining new competences or improving existing ones are increasingly being offered to teachers in the universities of the Republic of Poland in the form of e-learning both in distance and open education using digital technologies.

As noted, most of the teachers of management departments use digital technologies as a source of new information and an opportunity to improve their professional level in their professional activities in Polish universities. Within the framework of self-education teachers are attenders and participants of educational and scientific portals, sites, have their own electronic professional blogs, use the services of electronic libraries and bookshops, express their thoughts on online forums, collect information about conferences, seminars, courses, trainings, postgraduate education and are its active members, post their own e-portfolios and create websites reflecting personal and professional growth

According to the analysis of sources, questionnaires and interviews of teachers of the management departments, they prefer digital technologies in the process of supporting self-development management. Such digital platforms as Moodle, ELIAS and local USOS platform facilitate it. At the same time, LMS (Learning Management System) and LCMS (Learning Content Management System) are the dominant types of information systems used by the universities of the Republic of Poland. Teachers save time and money as digital systems, platforms and digital technologies offer a variety of forms and ways for developing existing and new competencies and enable to study without discontinuing from basic teaching activities and meet the requirements of students on placing materials for their usage.

Despite the urgency and great achievements in the application of digital technologies in the supporting process of the teacher self-development in universities of the Republic of Poland, there are a range of problems demanding to be addressed both by teachers and the senior managers of universities and its structural units (institutes, faculties, departments): to use digital technologies 
for the purpose of creation open access for participants of educational process to educational university content; to promote the motivation of teacher self-development; to create a system of mechanisms for stimulating teachers for the active use of digital technologies; to facilitate the creation of conditions for exercises, courses, trainings with the use of digital technologies at the university where the teacher works.

Perspectives for further studies in this area are the study and description of the conditions for the teacher professional growth of the management departments in the university of the Republic of Poland.

\section{References}

[1] Androshchuk I.M.: Self-Administration Form of Professional Teachers' Development within Departments of Management of Polish Higher Educationa Institutions in the Framework of Open Education System. Zhytomyr Ivan Franko State University Journal - Pedagogical Sciences 2 (93), 2018, 13-21.

[2] Basińska B.A., Garnik I. (red.): Zarządzanie informacyjnym środowiskiem pracy. Wydział Zarządzania i Ekonomii Politechniki Gdańskiej, Gdańsk 2014

[3] Becker-Pestka D., Kołodziej J., Pujer K.: Rozwój osobisty i zawodowy. Wybrane problemy teorii i praktyki. EXANTE, Wrocław 2017.

[4] Czarnecki K.: Teoretyczne podstawy zawodowego rozwoju człowieka. Zeszyty Naukowe Wyższej Szkoły Humaitas w Sosnowcu 2, 2007, 39.

[5] Europejski System Edukacji Elearningowej. URL

http://www.esee.eu/index.php?id=171 (Available: 12.06.2018).

[6] Garski K., Gontarz J. (red.): Jak efektywnie szkolić pracowników. PARP, Warszawa 2009

[7] Jankowski D.: Twórczy rozwój jednostki w całożyciowych procesach edukacji samoedukacji. Dialog o Kulturze i Edukacji 1/2012, 120-121.

[8] Kopciał P.: Analiza metod e-learningowych stosowanych w kształceniu osób dorosłych. Zeszyty Naukowe Warszawskiej Wyższej Szkoły Informatyki 9(7), 2013, 80 .

[9] Kozioł L.: Determinanty rozwoju e-learningu korporacyjnego. Zeszyty Naukowe Uniwersytetu Humanistyczno-Przyrodniczego w Siedlcach 98, 2013, 64-65.

[10] Kozioł M.: Wykorzystanie e-learningu w procesie szkolenia małych i średnich przedsiębiorstw. Zeszyty Naukowe Małopolskiej Wyższej Szkoły Ekonomii w Tarnowie 1, t. 22, 2013, 48.

[11] Król H., Ludwiczyński A. : Zarządzanie zasobami ludzkimi. Tworzenie kapitału ludzkiego organizacji. PWN, Warszawa 2007.

[12] Listwan T.: Kształcenie kadry menedżerskiej firmy. KADRY, Wrocław 1998.

[13] Ministerstwo Rozwoju Regionalnego: Strategia Rozwoju Kraju 2020.

Warszawa, 2012
URL:http://orka.sejm.gov.pl/Druki7ka.nsf/0/7938232EA0AAD4F2C1257AD00 052A8F6/\%24File/972.pdf (Available: 12.06.2018).

[14] Nauczyciel akademicki. URL: https://pl.wikipedia.org/wiki/Nauczyciel_akademicki (Available: 12.06.2018),

[15] Nowacki T.: Leksykon pedagogiki pracy, Wydawnictwo Instytutu Technologi Eksploatacji, Radom 2007.

[16] Oliynyk V.: Vidkryta pislyadyplomna pedahohichna osvita i dystantsiyne navchannya $\mathrm{v}$ zapytannyakh i vidpovidyakh. Universytet menedzhmentu osvity NAPN Ukrayiny, Kyyiv 2013.

[17] Społeczeństwo informacyjne w liczbach. Ministerstwo Administracji i Cyfryzacji, 2014. URL:

https://www.gov.pl/documents/31305/0/spoleczenstwo informacyjne_w liczbac h_2014_interactive_ok+\%281\%29.pdf/9c5e5068-5a03-6b80-ffb529eec1d46e2b (Available: 12.06.2018).

[18] Ustawa z dnia 27 lipca 2005 r. „Prawo o szkolnictwie wyższym”. Dz. U. $\mathrm{Nr} 164$, poz. 1365 z późniejszymi zmianami.

[19] Zapasa A.: Poradnik e-learningu. Świdnik 2011.

\section{Prof. Victor Oliynyk}

e-mail: vikt.oliynyk@gmail.com

Doctor of pedagogical sciences, professor, active member of National Academy of Educational Science of Ukraine, Honored Worker of Education of Ukraine, Advisor to Rector of the State Higher Educational Institution "University of Educational Management" of the National Academy of Educational Sciences of Ukraine. Kyiv.

ORCID ID: 0000-0002-2576-0722

\section{Ph.D. Iryna M. Androshchuk}

e-mail: irenandro@gmail.com

Ph.D. in Education, Professor of the Department of Pedagogy, Management and Administration of the Education and Scientific Institute of Management and Psychology of the State Higher Educational Institution "University of Educational Management" National Academy of Educational Sciences of Ukraine, doctoral student at the State Higher Educational Institution "University of Educational Management" of the National Academy of Educational Sciences of Ukraine, Kyiv.

ORCID ID: 0000-0002-3557-793X

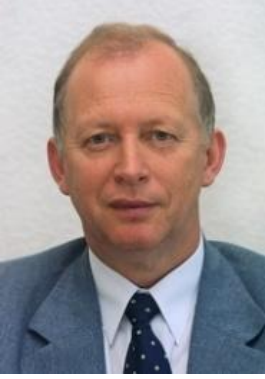

otrzymano/received: 22.08 .2018

przyjęto do druku/accepted: 15.09 .2018 